\title{
Social Psychology
}

National Cancer Institute

\section{Source}

National Cancer Institute. Social Psychology. NCI Thesaurus. Code C17033.

The branch of psychology that studies persons and their relationships with others and with groups and with society as a whole. 